UDC 81'271.16

Submitted: 03.10.2019

LBC 81.006

Accepted: 27.12 .2019

\title{
COMMUNICATIVE AND PRAGMATIC EFFECTS OF A NEGATIVE FORECAST IN TERMS OF DETERMINING AN INDECENT UTTERANCE ${ }^{1}$
}

\author{
Oksana S. Issers \\ Dostoevsky Omsk State University, Omsk, Russia
}

\begin{abstract}
The article discusses the use of speech act of a negative forecast affecting the personal sphere of the addressee in order to insult him. The indecent semantics of an utterance that violates ethical norms and communication conventions is considered as one of the indecent forms (methods) of expression. Pragmatics presents the study of the ethical aspect of communication in the conversational postulates, the principles of politeness. However, these principles can hardly be used for linguistic examination to detect the infliction of psychological damage. The affecting negative forecast is of undoubted interest for the theory and practice of linguistic examination, since the influence of a forecasting text may cause psychological harm to the addressee in the form of humiliation of his honor and dignity. Since the negative forecast often represents a mixture of fact and predictive version it becomes an effective tool of influence. Critical publications in Omsk media are analyzed to consider the problem of detection of indecent form as a way of transference of indecent content in the speech act of a negative forecast. The author concludes that a speech act of negative forecast with taboo or ethically questionable semantics can be considered as a marker of indecent form. The emotional nature of the forecasting text makes it an effective tool for influencing the personality and its psychological sphere. This provides an added incentive for an in-depth study of these issues in the aspect of the legal assessment of verbal aggression and cases of offence in particular.
\end{abstract}

Key words: forecast, speech act, indecent form, linguistic expertise, insult, communicative norms.

Citation. Issers O.S. Communicative and Pragmatic Effects of a Negative Forecast in Terms of Determining an Indecent Utterance. Vestnik Volgogradskogo gosudarstvennogo universiteta. Seriya 2. Yazykoznanie [Science Journal of Volgograd State University. Linguistics], 2020, vol. 19, no. 1, pp. 41-51. (in Russian). DOI: https:// doi.org/10.15688/jvolsu2.2020.1.4

УДК 81'271.16

Дата поступления статьи: 03.10.2019

ББК 81.006

Дата принятия статьи: 27.12.2019

\section{КОММУНИКАТИВНО-ПРАГМАТИЧЕСКИЕ ЭФФЕКТЫ НЕГАТИВНОГО ПРОГНОЗА В АСПЕКТЕ УСТАНОВЛЕНИЯ НЕПРИЛИЧНОЙ ФОРМЫ ВЫСКАЗЫВАНИЯ ${ }^{1}$}

\author{
Оксана Сергеевна Иссерс \\ Омский государственный университет им. Ф.М. Достоевского, г. Омск, Россия
}

\begin{abstract}
Аннотация. В статье обсуждается использование речевого акта негативного прогноза, затрагивающего личную сферу адресата, в целях оскорбления. Неприличная семантика высказывания, нарушающая этические нормы и коммуникативные конвенции, рассматривается как одно из проявлений неприличной формы (способа) высказывания. Этический аспект коммуникации отражен в постулатах речевого общения, принципах вежливости, однако сформулированы они недостаточно конкретно, в связи с чем трудно применимы в лингвистической экспертизе для установления факта оскорбления. Для теории и практики экспертизы воздействующий потенциал негативного прогноза представляет интерес, поскольку результатом влияния прогностического текста может быть нанесение психологического вреда адресату в виде унижения его чести и достоинства. Выявлено, что негативный прогноз нередко строится на основе смешения факта и прогности() ческой версии. Это делает его эффективным инструментом воздействия. Проблема установления неприлич-
\end{abstract}


ной формы как способа передачи непристойного содержания в речевом акте негативного прогноза рассмотрена на материале публикаций в СМИ. Автор приходит к выводу о правомерности выделения речевого акта негативного прогноза с табуированной или этически сомнительной семантикой в качестве маркера неприличной формы. Это предоставляет дополнительную возможность для аргументированной экспертизы конфликтных текстов.

Ключевые слова: прогноз, речевой акт, неприличная форма, лингвистическая экспертиза, оскорбление, коммуникативные нормы.

Цитирование. Иссерс О. С. Коммуникативно-прагматические эффекты негативного прогноза в аспекте установления неприличной формы высказывания // Вестник Волгоградского государственного университета. Серия 2, Языкознание. - 2020. - Т. 19, № 1. - C. 41-51. - DOI: https://doi.org/10.15688/jvolsu2.2020.1.4

\section{Введение}

Установление неприличной формы высказывания является основанием для квалификации административного правонарушения по ст. 5.61 КоАП «Оскорбление» и относится к одной из традиционных задач лингвистической экспертизы. В диспозиции данной статьи оскорбление рассматривается как «унижение чести и достоинства другого лица, выраженное в неприличной форме» (КоАП). Соответственно, в задачи лингвистической экспертизы по делам об оскорблении входят: 1) установление перлокутивного эффекта речевого воздействия, оказанного на адресата (он испытывает унижение собственной чести и достоинства); 2) установление неприличной формы высказывания. Каждая из этих задач в теории и практике экспертной деятельности имеет свои дискуссионные аспекты. Остановимся на каждом из них.

Унижение чести и достоинства отличается от опорочения тем, что устанавливается на основании нанесения вреда (психологической травмы) не репутации личности, а самой личности [Иссерс, 1999, с. 107]. В отличие от ст. 152 ГК РФ о защите чести, достоинства и деловой репутации, где порочащий характер распространенных сведений устанавливается на основе ущерба для репутации истца, унижение как событие возможно в сфере как публичной, так и межличностной коммуникации: нанесение психологической травмы предполагает в первую очередь коммуникативную установку субъекта речи на то, чтобы заставить адресата испытать унижение. В связи с этим перед экспертом стоит задача реконструировать намерение (интенцию) нанести оскорбление.

Одним из очевидных решений в подобных случаях является установление страте- гии дискредитации - именно это понятие стало ключевым для судебно-лингвистического моделирования события оскорбления [Баранов, 2007, с. 537-552; Бринев, 2009, с. 86-94; Немирова, 2015]. Однако психологический вред для личности могут наносить не только сведения, порочащие его публичное «лицо». Как отмечает М.А. Осадчий, оскорбительным может стать высказывание, имеющее или не имеющее модус субъективного мнения, содержащее или не содержащее пропозицию «S coвершает $\mathrm{P»}$, где $\mathrm{P}$ - действие порочащего характера [Осадчий, 2012, с. 71].

Поскольку проблема установления факта нанесения психологического вреда (и в его результате - психической травмы) выходит за рамки лингвистической экспертизы, задача лингвиста - установить нарушение этических норм коммуникации, которое привело к унижению чести и достоинства адресата. В какой форме и где они эксплицированы?

В явном виде эти нормы закреплены в различных профессиональных и корпоративных кодексах. Однако очевидно, что такого рода кодексы редко включают коммуникативные аспекты речевого поведения. Исключением может быть «Кодекс профессиональной этики российского журналиста»: «Журналист распространяет и комментирует только ту информацию, в достоверности которой он убежден и источник которой ему хорошо известен. Он прилагает все силы к тому, чтобы избежать нанесения ущерба кому бы то ни было ее неполнотой или неточностью, намеренным сокрытием общественно значимой информации или распространением заведомо ложных сведений» (Кодекс, 1994).

Этическим аспектам коммуникации посвящены в значительной своей части прагматические постулаты речевого общения 
(Г.П. Грайса, Дж. Лича и др.). Однако сформулированы они достаточно общо, а их нарушение далеко не всегда свидетельствует о конфликтогенной стратегии говорящего (на нарушении некоторых постулатов регулярно строятся импликатуры). Таким образом, указанные нормы трудно применимы для установления факта нанесения психологического вреда.

Вербальная агрессия как проявление неэтичного поведения и законодательно наказуемое действие имеет длительную традицию изучения и в России, и за рубежом. В соответствии с определением американских юристов, к случаям вербального оскорбления следует относить высказывания, цель которых заключается в провоцировании у слушающего немедленной отрицательной реакции [Nowak, Rotunda, Young, 1986].

В отечественной теории культуры речи следование коммуникативной этике входит в число основных компонентов речевой культуры. Коммуникативная, или речевая, этика определяется как «правила должного речевого поведения, основанные на нормах морали, национально-культурных традициях» [Культура русской речи, 2007, с. 287].

На фоне недостаточно четко эксплицированных критериев для определения этических норм коммуникации в качестве более надежного параметра для установления унижения чести и достоинства личности может быть рассмотрено нарушение приличий, связанных с употреблением языка.

В практике лингвистической экспертизы установление неприличной формы высказывания обычно строится на основании его ортологической оценки, в частности на выявлении стилистических словарных помет, маркирующих «жесткие» инвективы [Бельчиков, 2002; Бринев, 2009, с. 104-106; Коряковцев, Головачева, 2004; Кусов, 2013; Осадчий, 2012, c. 85 ; и др.]. Употребление обсценных слов и выражений, а также форм, содержащих непристойность, в русской речевой культуре рассматривается как «абсолютная норма неприличия» по отношению к использованию языковых средств [Бринев, 2009, с. 107]. Несмотря на ряд дискуссионных проблем, касающихся несовершенства лексикографических принципов словарных помет [Голев, 2002, с. 123], процедура ортологической характеристики представляется вполне отработанной в практике лингвистической экспертизы. Однако установление «неприличной формы» не исчерпывается словарным подходом. На наш взгляд, понятие «неприличная форма» (в широком смысле) должно рассматриваться в контексте содержания высказывания, то есть через оценку избранного адресантом способа выражения конфликтогенной интенции.

Характеристика неприличного содержания применительно к русской культуре основывается, как правило, на описании того, что «может быть неприличным» в социальном поведении. В.И. Жельвис относит к инвективе (в узком смысле) любые речевые акты словесной агрессии, воспринимаемые в данной социальной группе как резкие или табуированные: «инвективой можно назвать нарушение этического табу, осуществленное некодифицированными (запрещенными) средствами» [Жельвис, 2000, с. 225]. Однако в отсутствие списка конкретных речевых актов, которые с большой вероятностью соответствовали бы указанным выше характеристикам, сфера «неприличного» речевого поведения за границами конкретного словоупотребления оказывается также недостаточно определенной. Этот вопрос приобретает особую актуальность в юридической плоскости: в диспозиции ст. 5.61 КоАП зафиксирован термин «неприличная форма», в то время как неприличным может быть и содержание [Осадчий, 2012 , с. 87]. Этой же позиции придерживается В.Ю. Меликян, считающий ничем не оправданной трактовку термина «неприличная форма» исключительно в лингвистическом аспекте - как «неприличная форма языковой единицы». По его мнению, юридический термин «неприличная форма» является неудачным в силу своей оценочности и размытости границ толкования [Меликян, 2019] (см. об этом также: [Балова, Будаева, Щербань, 2014]).

Одним из критериев соблюдения приличий служит учет табуированных смыслов и тем. По мнению И.А. Стернина, неприличие (непристойность) содержания - это нарушение тематических табу в общении, затрагивание и обсуждение тем, которые в обществе считаются недопустимыми в публичном обсуждении (секс, телесный низ и т. п.) [Стер- 
нин, 2008, с. 226]. Однако запреты, связанные с понятием «неприличного», могут касаться не только тематического репертуара, но и некоторых коммуникативных (речевых) актов, которые затрагивают личную сферу адресата. К их числу относится негативный прогноз.

\section{Материал и методы исследования}

Речевой акт прогноза соотносится с описанием будущего события или ситуации, которые, по мнению говорящего, должны произойти. В соответствии с указанной особенностью он реализуется в модальности предположения (версии, отнесенной к будущему). Как отмечают исследователи, прогностический текст всегда нацелен не только на передачу образа моделируемого будущего, но и на передачу актуального для автора эмотивного содержания. «Прогностический текст эмотивен по своей сути, так как будущее никогда не воспринимается человеком нейтрально» [Cолопова, Ворошилова, 2018, с. 142]. Для любой проекции в будущее стимулом является интенция отправителя сообщения - желание воздействовать на адресата, на его мотивы, желания, страхи. Это ярко демонстрирует политический и массмедийный дискурсы [Немирова, 2015; Солопова, 2017; Шейгал, 2000; Chudinov, Solopova, 2015], но воздействующий потенциал прогностического текста этими сферами отнюдь не ограничивается.

Так, в межличностной коммуникации используется прогностический сценарий «во благо», где настоящее адресата интерпретируется как позитивное на фоне худшего будущего, которого удалось избежать (примеры подобного рода рассматриваются в статье: [Азнабаева, Анищенко, 2017]).

Для практики лингвистической экспертизы воздействующий потенциал негативного прогноза представляет несомненный интерес, поскольку его результатом может быть нанесение психологического вреда адресату в виде унижения его чести и достоинства.

По классификации Дж. Серля, прогноз относится к речевым актам, которые автор определил как репрезентативы: их иллокутивная цель - описывать определенное положение дел; исполняя их, говорящий возлагает на себя ответственность за истинность сообще- ния [Серль, 1999, с. 240]. При этом Дж. Серль замечает, что степень убеждения и ответственности говорящего за высказанные суждения о настоящем или будущем положении дел «может приближаться к нулю или даже быть ему равной [Серль, 1999, с. 240]. В связи с этим можно выделить такие вариации прогноза, как предположение, версия, опасение и др.

Отнесенность прогноза к сфере предполагаемых событий, как правило, маркируется соответствующими показателями. Ядерными средствам выражения будущего в прогностическом тексте являются видо-временные формы футурума, ближнюю периферию составляют формы презенса, а дальнюю - видовременные формы прошедшего времени, модальные глаголы и другие разноуровневые средства [Солопова, Ворошилова, 2018, с. 152].

Лингвисты-эксперты отмечают, что «опасность» негативного прогноза в аспекте стратегии дискредитации и оказания отрицательного психологического воздействия на того, кто является действующим лицом прогностического сценария, связана со смешением показателей модальности предположения и модальности факта. Отсутствие маркеров модальности предположения в отдельных фрагментах текста воспринимается как результат логического вывода о фактическом положении дел. Это создает основания для смешения факта и прогностической версии, в результате чего происходит дезориентация адресата (см. об этом: [Баранов, 2007, с. 226-228]).

Проблема установления неприличной формы как способа передачи непристойного содержания в речевом акте негативного прогноза будет рассмотрена на материале кейса «Журналист Власов против журналистки Яковлевой».

\section{Результаты и обсуждение}

В 2017 г. в статье Виктора Власова «"Учительская газета” не любит учителей?», опубликованной на нескольких интернет-платформах, была размещена негативная информация о журналистке Н. Яковлевой, ставшая основанием для предъявления судебного иска к автору статьи.

В. Власов обсуждает публикацию своей коллеги Н. Яковлевой по поводу конфликта 
между школьным учителем и ее дочерью, который стал предметом дискуссии в СМИ. Несмотря на то что объектом критических оценок В. Власова является мать ребенка, в статье содержатся развернутые рассуждения по поводу тринадцатилетней дочери журналистки Н. Яковлевой - Ангелины и, в частности, ее рисунка, размещенного на портале омского журнала «Бизнес-курс». Эти рассуждения носят характер версий, связанных с возможным психическим нездоровьем Ангелины, обусловленным невниманием к состоянию дочери со стороны матери:

В статье товарища А. Гошкодера размещен рисунок Ангелины. Обратите внимание на цвета, на манеру рисования и настроение. Рассмотрите девочку, у которой зашит рот. Картинка добротная, правда, но смотришь на нее, и плакать хочется. Вдруг ребенок склонен к суициду? А мама-то не видит, не чувствует? (Выделено нами. - О. И.) Сколько закрадывается мрачных мыслей. Автор этого рисунка - словно чудак из страны глумливых чудес, душевно больной иллюстратор, имеет «Синдром звездного шрама» - «Геостигму», болезнь, придуманную в японском мультфильме «Последняя фантазия 7: Дети пришествия» - по нашумевшей и популярной видеоигре «FF7» на консоли «PlayStation». Продолжать анализировать можно хоть сколько, выдумывая и доводя контуры, так сказать. Не хочется и самому попасть в корпус для нездоровых душевно или нарваться на беседу с работником соответствующей службы...

Что получается, ребенок практически «обречен» на психологические проблемы! Испытывая дефицит воспитательного влияния и родительского общения, он восполнит пустоту, как сможет, например, уйдет от реальности в виртуальный мир или в разгульный образ жизни, где его понимают, принимают. А отсутствие поддержки, когда ребенок не справляется с психологической нагрузкой, грозит погружением в депрессию, и как следствие - прием спиртного и наркотиков, и даже самоубийство ${ }^{2}$ (Власов).

Вероятно, не требуется специальных психологических знаний, чтобы выразить мнение: любому родителю подобный прогноз нанесет психологический вред. Тем не менее, в соответствии с диспозицией ст. 5.61 КоАП, высказывание может характеризоваться как оскорбление в случае, если оно не только потенциально унижает честь и достоинство, но и неприлично по своей форме. Обоснован- ным представляется вопрос, поставленный М.А. Осадчим: «Может ли неприличная семантика высказывания стать неприличной формой унижения чести и достоинства?» [Осадчий, 2012, с. 87]. Мы склонны согласиться с автором в том, что с номинативной точки зрения в контексте статьи КоАП слово форма использовано не в значении «внешняя оболочка», а в значении «способ» (унижение чести и достоинства другого лица неприличным способом), поскольку неприличная семантика может быть выражена и невербальным способом.

В связи с этим вопрос эксперту был сформулирован так: «В какой форме - приличной или неприличной - выражена оценка личности Н. Яковлевой? В частности, имеются ли в тексте статьи фрагменты, которые можно рассматривать как нарушения коммуникативных табу? Можно ли считать семантику, связанную со сделанным автором статьи прогнозом заболевания (в том числе психического), табуированной в русской лингвокультуре?»

Лексическое значение слова неприличныци 'не соответствующий, противоречащий правилам приличия, хорошего тона, непристойный' (Большой толковый словарь) отражает корреляцию коммуникативно-этических и языковых категорий - приличия и нормы. Однако далеко не для всех фактов использования языка вопрос о нормативности решается одинаково. Кодифицированные и некодифицированные нормы существенно различаются по их эксплицитности и обязательности выполнения членами социума. Для некодифицированных норм определение по шкале «прилично / неприлично» основано на оценке высказывания как конкретного дискурсивного акта в контексте ситуации общения и современных дискурсивных практик. При анализе высказывания в аспекте коммуникативной ситуации нельзя обойтись без учета коммуникативных табу и ограничений.

Табу и более мягкие принятые в обществе тематические ограничения относятся к некодифицированным нормам, поэтому коммуникативный риск их нарушения может различаться. В частности, в современной русской лингвокультуре, как типично европейской и христианской, табуированными являются образы телесного низа, экскрементов, полового акта и 
акта дефекации и т. д. [Осадчий, 2012, с. 132]. Однако табуированные темы и образы этим списком отнюдь не исчерпываются. Так, к коммуникативным табу, на наш взгляд, относятся разного рода предсказания и прогнозы болезней, сделанные не врачами и относящиеся как к адресату, так и к третьим лицам, в том числе их близким (Жить тебе осталось недолго! Твой ребенок умрет от страшной болезни!).

По своей коммуникативной интенции приведенный фрагмент статьи В. Власова следует рассматривать как мрачный прогноз (сколько закрадыввается мрачных мыслей). В рамках общечеловеческих ценностей семья и дети входят в сферу человеческой личности и составляют ее неотъемлемую часть. Таким образом, сами по себе прогнозы, связанные с возможным психическим либо физическим нездоровьем членов семьи, особенно детей, наносят личности психологическую травму. Предположения и прогнозы медицинского характера, сделанные не профессиональным психологом, а дилетантом, являются нарушением как врачебных норм, так и коммуникативно-этических табу. Выбранная автором форма рассуждений претендует на анализ (продолжать анализировать можно сколько угодно), что еще более усиливает воздействие на читателя статьи и повышает суггестивный эффект прогноза.

В качестве дополнительного воздействующего эффекта при введении в сознание адресата актуальной для отправителя информации традиционно используется экспертное мнение. Журналист В. Власов включает в текст статьи мнение анонимного психолога из АН ПОО «Многопрофильная Академия непрерывного образования»:

Человеку свойственно в той или иной мере желание стать более знаменитым, значимым для общества или определенного круга людей, - комментирует сотрудник академии. - Кто-то создает проекты, реализует идеи, а кто-то начинает играть на публику, по суги, реализуется за счет других. К сожалению, у публичных людей, особенно если они "пиарятся" антисоциальными способами, как правило, страдают дети (выделено нами. - О. И.) (Власов).

Мнение построено по модели «общих рассуждений» и вроде бы оставляет читате- лю возможность самому сделать заключение о референте данного мнения (то есть к кому относятся выводы психолога). Однако логика построения статьи, где большая часть оценок была дана личности и профессиональным качествам журналистки Н. Яковлевой, а предшествующая экспертному мнению часть прогнозам В. Власова о будущем или настоящем психическом нездоровье ее дочери Ангелины, не позволяет установить иной объект референции, кроме Натальи Яковлевой. Именно она и есть публичный человек, который «пиарится» антисоциальными способами, и именно у нее «страдают дети».

Приведенные после экспертного мнения выводы автора статьи построены путем навязывания логического вывода, что является традиционным приемом скрытого (имплицитного) введения знаний в модель мира адресата:

Что получается, ребенок практически «обречен» на психологические проблемы! Исn bытывая дефицит воспитательного влияния и родительского общения, он восполнит пустоту, как сможет, например, уйдет от реальности в виртуальный мир или в разгульный образ жсизни, где его понимают, принимают. А отсутствие поддержки, когда ребенок не справляется с психологической нагрузкой, грозит погружением в депрессию, и как следствие - прием спиртного и наркотиков, и даже самоубийство (выделено нами. - О. И.) (Власов).

Гипотеза автора относительно ребенка, по поводу здоровья которого запрашивалось экспертное мнение, имеет непосредственное отношение к характеристике его родителей (в данном случае матери - Н. Яковлевой) и независимо от степени ее отношения к реальному положению дел нарушает принятые в русской лингвокультуре социальные нормы.

Таким образом, мнение автора статьи В. Власова о личностных качествах журналистки Н. Яковлевой выражается следующими пропозициями: она пиарится антисоциальными способами; ее дочь испытывает дефицит воспитательного влияния (= она плохой родитель); эти качества матери могут повлиять на будущее ребенка и довести его до самоубийства. Все указанные умозаключения, высказанные публично, при оценке их нормативности и социальной приемлемости должны рассматриваться как содержащие табуирован- 
ную в русской лингвокультуре семантику и нарушающие этику общения.

Дискредитирующая сила негативного прогноза, как указано выше, нередко бывает обусловлена смешением показателей модальности предположения и модальности факта. Это наглядно иллюстрирует фрагмент рассматриваемой статьи:

Автор этого рисунка - словно чудак из страны глумливых чудес, душевно больной иллюстратор, имеет «Синдром звездного шрама» - «Геостигму», болезнь, придуманную в японском мультфильме «Последняя фантазия 7: Дети пришествия»... Продолжать анализировать можно хоть сколько, выдумывая и доводя контуры, так сказать. Не хочется и самому попасть в корпус для нездоровых душевно или нарваться на беседу с работником соответствующей службы. Художнник-иллюстратор и автор рисунка в статье А. Гоикодера увлекается просмотром анимэ жанра «Тентакли», лучше не ищите определение этого слова, пожалуйста (выделено нами. - О. И.) (Власов).

Последнее высказывание по своей грамматической форме и лексическому наполнению является утверждением о фактах, поскольку не содержит речевых средств, указывающих на предположение, сомнение, мнение говорящего. Предшествующие фразы: Продолжать анализировать можно хоть сколько, выдумыввая и доводя контуры, так сказать. Не хочется и самому попасть в корпус для нездоровых душевно или нарваться на беседу с работником соответствующей службы - можно рассматривать как намерение автора прекратить свои действия, обозначенные как вылумыввать, из чего следует, что последнее высказывание претендует на фиксацию реальных фактов.

Специфика синтаксического построения высказываний данного фрагмента такова, что читатель не всегда может отличить сравнительные и гипотетические конструкции от утверждений о реальном положении дел. Так, во фрагменте: Автор этого рисунка - словно чудак из страны глумливых чудес, душевно больной иллюстратор, имеет «Синдром звездного ирама» - «Геостигму» - границы сравнительной конструкции могут определяться двояко:

(а) автор этого рисунка - / словно чудак из страны глумливых чудес, душевно больной иллюстратор, / имеет «Синдром звездного ирама»;

(б) автор этого рисунка - / словно чудак из страны глумливых чудес, / душевно больной иллюстратор, имеет «Синдром звездного ирама».

В случае интерпретации (а) утверждается, что автор рисунка (Ангелина Яковлева) имеет «Синдром звездного шрама».

В случае интерпретации (б) утверждается, что автор рисунка - душевно больной иллюстратор и имеет «Синдром звездного шрама».

Учитывая повторное использование номинации автора рисунка иллюстратор (Художник-иллюстратор и автор рисунка в статье А. Гошкодера увлекается просмотром анимэ жанра «Тентакли»), можно сделать логический вывод о том, что интерпретация (б) наиболее вероятна и, следовательно, данный субъект (автор рисунка, Ангелина, дочь журналистки Яковлевой) душевно болен. Последнее, по сути, имеет форму психиатрического диагноза, поставленного журналистом, и нарушает нормы профессиональной и общечеловеческой этики.

Это позволяет на вопрос, заданный эксперту, дать следующий ответ: «Оценка личности Н. Яковлевой выражена в неприличной форме негативного прогноза, связанного с нарушениями коммуникативно-этических табу. Семантику данного прогноза, сделанного журналистом В. Власовым по поводу психического заболевания ребенка Н. Яковлевой, следует рассматривать как табуированную, причем как в русской, так и в европейской лингвокультуре.

\section{Заключение}

На основании представленного выше кейса можно сделать вывод о правомерности выделения речевого акта негативного прогноза с табуированной или этически сомнительной семантикой, затрагивающей личную сферу адресата, в качестве маркера неприличной формы. При этом задача установления лингвокультурологического фона, на котором оценивается этическая корректность прогноза, ложится на плечи эксперта. Так, можно обсуждать допустимость «эсхатологических» прогнозов в публицистике экологической на- 
правленности, когда неблагоприятный исход событий, описанный в гиперболизированной форме, потенциально ущемляет честь и достоинство якобы «виновника», как, например, в следующем фрагменте статьи о владельце крупного международного холдинга, выпускающего технический углерод:

Получается, нам нужно ждать массового мора жителей прилегающего к сажевому заводу поселка, чтобы заставить того же Каплуната... тратить хотя бы малую часть этих денег на новые экостандарты? (Как Путин..., с. 21).

Обозначение руководителя компании в качестве потенциального виновника «массового мора» негативно воздействует не только на читателей издания, но и на самого «фигуранта». Этическая составляющая подобных прогнозов требует экспертной оценки.

Вероятно, к дискуссионным вопросам, возникающим в связи с квалификацией унижения чести и достоинства в неприличной форме, следует отнести разного рода негативные прогнозы в отношении здоровья, благополучия, перспектив в профессиональной и личной сферах человека.

Свойство прогноза навязывать излишне доверчивым наблюдателям (читателям) свои допущения, а также эмотивный характер прогностического текста делают его эффективным инструментом воздействия на личность и ее психологическую сферу, что является дополнительным стимулом для углубленного изучения данных вопросов в аспекте правовой квалификации события «оскорбление».

\section{ПРИМЕЧАНИЯ}

${ }^{1}$ Исследование выполнено при финансовой поддержке РФФИ и Правительства Омской области в рамках научного проекта № 18-412-550001.

The reported study was funded by RFBR and the Government of Omsk Region in the framework of research project no. 18-412-550001.

2 Здесь и далее в приведенных примерах орфография и пунктуация автора сохранены.

\section{СПИСОК ЛИТЕРАТУРЫ}

Азнабаева Л. А., Анищенко А. А., 2017. Аргументативный эмпатийный речевой акт негатив- ного прогноза «во благо» // Вестник Башкирского университета. Т. 22. № 1. С. 265-269.

Балова И. М., Будаева Л. А., Щербань Г. Е., 2014. Условность определения приличности / неприличности формы выражения оскорбления // Язык и право: актуальные проблемы взаимодействия. Вып. 4 : материалы IV Bсерос. науч.-практ. конф. (Ростов-на-Дону, 1530 ноября 2014 г.) / отв. ред. В. Ю. Меликян. Ростов н/Д : Дониздат. С. 226-234.

Баранов А. Н., 2007. Лингвистическая экспертиза текста: теория и практика. М. : Флинта. 592 с.

Бельчиков Ю. А., 2002. Инвективная лексика в контексте некоторых тенденций в современной русской речевой комуникации // Филологические науки. № 4. С. 66-74.

Бринев К. И., 2009. Теоретическая лингвистика и судебная лингвистическая экспертиза : монография / под ред. Н. Д. Голева. Барнаул : АлГПА. 252 c.

Голев Н. Д., 2002. Об объективности и легитимности источников лингвистической экспертизы // Юрислингвистика-3 : Проблемы юрислингвистической экспертизы : межвуз. сб. науч. тр. / под ред. Н. Д. Голева. Барнаул : Изд-во АГУ. С. 110-123.

Жельвис В. И., 2000. Слово и дело: юридический аспект сквернословия // Юрислингвистика-2 : Русский язык в его естественном и юридическом бытии : межвуз. сб. науч. тр. / под ред. Н. Д. Голева. Барнаул : Изд-во Алт. гос. ун-та. С. 223-235.

Иссерс О. С., 1999. Свобода слова: две стороны медали (оскорбление в зеркале юриспруденции и лингвистики) // Юрислингвистика-1 : Проблемы и перспективы : межвуз. сб. науч. тр. / под ред. Н. Д. Голева. Барнаул : Изд-во Алт. ун-та. С. 106-121.

Коряковцев А. В., Головачева О. В., 2004. К проблеме инвективного функционирования языка и лексикографического описания русской инвективной лексики // Юрислингвистика: юридические аспекты языка и лингвистические аспекты права / под ред. Н. Д. Голева. Барнаул : Изд-во Алт. ун-та. С. 216-225.

Культура русской речи, 2007 : энцикл. слов.-справ. / под ред. Л. Ю. Иванова [и др.]. 2-е изд, испр. М. : Флинта : Наука. 840 с.

Кусов Г. В., 2013. Диагностика квалифицирующего признака «неприличная форма» в судебной лингвистической экспертизе // Культура и текст. № 1 (14). С. 93-114.

Меликян В. Ю., 2019. Методология и практика юридизации инвективной лексики // IX Всероссийская научно-практическая конференция «Язык и право : Актуальные проблемы взаи- 
модействия» (15 ноября 2019 г.). URL: http:// www.ling-expert.ru/conference/langlaw9/ melikyan-2019.html (дата обращения: 12.10.2019).

Немирова Н. В., 2015. Прецедентность политического прогнозирования в газетном дискурce // Политическая лингвистика. № 3 (53). С. $148-155$.

Осадчий М. А., 2012. Русский язык на грани права : Функционирование русского языка в условиях правовой регламентации речи. М. : ЛИБРОКОМ. 254 с.

Серль Дж. Р., 1999. Классификация иллокутивных актов // Зарубежная лингвистика. Вып. II / общ. ред. В. А. Звягинцева, Б. А. Успенского, Б. Ю. Городецкого. М. : Прогресс. С. 229-253.

Солопова О. А., 2017. Метафора в моделировании будущего: «светлый» сценарий (на материале прогностических текстов о России отечественного, американского и британского политических дискурсов XXI века) // Вестник Томского государственного университета. Филология. № 46. С. 55-70. DOI: 10.17223/ 19986645/46/5.

Солопова О. А., Ворошилова М. Б., 2018. Эмотивный потенциал прогностического текста (на материале британского политического дискурса XIX века) // Коммуникативные исследования. № 4 (18). С. 141-156. DOI: 1025513/2413-6182.2018.4.141-156.

Стернин И. А., 2008. Избранные работы. Теоретические и прикладные проблемы языкознания / науч. ред. 3. Д. Попова. Воронеж : Истоки. $596 \mathrm{c}$.

Шейгал Е. И., 2000. Категория прогностичности в политическом дискурсе // Язык, сознание, коммуникация : сб. ст. / отв. ред. В. В. Красных, А. И. Изотов. М. : МАКС-Пресс. Вып. 14. C. 77-83.

Chudinov A. P., Solopova O. A., 2015. Linguistic Political Prognostics: Models and Scenarios of Future // Procedia - Social and Behavioral Sciences. Vol. 200. P. 412-417.

Nowak J., Rotunda R., Young J., 1986. Constitutional Law. $3^{\text {rd }}$ ed. St. Paul, MN : West. 1191 p.

\section{ИСТОЧНИКИ И СЛОВАРИ}

Большой толковый словарь - Большой толковый словарь русского языка / гл. ред. С. А. Кузнецов. СПб. : Норинт, 1998. 1534 с. URL: http:// gramota.ru/slovari/dic (дата обращения: 12.07.2019).

Власов - Власов В. «Учительская газета» не любит учителей? URL: http://nasha-molodezh.ru/ blogs/viktor-vlasov/uchitelskaya-gazeta-ne- lyubit-uchiteley.html (дата обращения: 12.07.2019)

ГК РФ - Гражданский кодекс Российской Федерации. URL: https://base.garant.ru/10164072/ (дата обращения: 12.07.2019).

Как Путин... - Как Путин посягал на честь сажевого олигарха. И чем это кончилось // Бизнес Курс. 2018. № 21. С. 20-21.

КоАП-Кодекс РФ об административных правонарушениях. URL: http://koapkodeksrf.ru/ (дата обращения: 12.07.2019).

Кодекс - Кодекс профессиональной этики российского журналиста Союза журналистов России. 1994. URL: https://www.presscouncil.ru/ teoriya-i-praktika/dokumenty/633-kodeksprofessionalnoj-etiki-rossijskogo-zhurnalista (дата обращения: 12.06.2019).

\section{REFERENCES}

Aznabaeva L.A., Anischenko A.A., 2017. Argumentativnyy empatiynyy rechevoy akt negativnogo prognoza «vo blago» [Argumentative Empathic Speech Act of Negative Prognosis "For the Benefit"]. Vestnik Bashkirskogo universiteta [Bulletin of Bashkir University], vol. 22, no. 1, pp. 265-269.

Balova I.M., Budaeva L.A., Scherban G.E., 2014. Uslovnost opredeleniya prilichnosti / neprilichnosti formy vyrazheniya oskorbleniya [Conventionality of Determining Decent / Indecent Forms of Expression of Insult]. Melikyan V.Yu., ed. Yazyk i pravo: aktualnye problemy vzaimodeystviya. Vyp. 4: materialy IV Vseros. nauch.-prakt. konf. (Rostov-na-Donu, 15-30 noyabrya 2014 g.) [Language and Law: Actual Problems of Interaction. Iss. 4. Proceedings of the $4^{\text {th }}$ All-Russian Scientific and Practical Conference (Rostov-on-Don, November 15-30, 2014)]. Rostov-on-Don, Donizdat, pp. 226-234.

Baranov A.N., 2007. Lingvisticheskaya ekspertiza teksta: teoriya $i$ praktika [Linguistic Examination of the Text: Theory and Practice]. Moscow, Flinta Publ. 592 p.

Belchikov Yu.A., 2002. Invektivnaya leksika v kontekste nekotorykh tendentsiy $\mathrm{V}$ sovremennoy russkoy rechevoy komunikatsii [Invective Vocabulary in the Context of Some Trends in Modern Russian Speech Communication]. Filologicheskie nauki [Philological Sciences], no. 4, pp. 66-74.

Brinev K.I., 2009. Teoreticheskaya lingvistika $i$ sudebnaya lingvisticheskaya ekspertiza: monografiya [Theoretical Linguistics and 
Forensic Linguistic Examination. Monograph]. Barnaul, AltGPA. 252 p.

Golev N.D., 2002. Ob obyektivnosti i legitimnosti istochnikov lingvisticheskoy ekspertizy [On the Objectivity and Legitimacy of the Sources of Linguistic Examination]. Golev N.D., ed. Yurislingvistika-3: Problemy yurislingvisticheskoy ekspertizy: mezhvuz. sb. nauch. tr. [Legal Linguistics-3: Problems of Legal Linguistic Examination. Interuniversity Collection of Scientific Works]. Barnaul, Izd-vo AGU, pp. 110-123.

Zhelvis V.I., 2000. Slovo i delo: yuridicheskiy aspekt skvernosloviya [The Word and the Action: The Legal Aspect of Dirty Language]. Golev N.D., ed. Yurislingvistika-2: Russkiy yazyk v ego estestvennom i yuridicheskom bytii: mezhvuz. sb. nauch. tr. [Legal Linguistics-2: Russian Language in Its Natural and Legal Existence]. Barnaul, Izd-vo Altayskogo gosudarstvennogo universiteta, pp. 223-235.

Issers O.S., 1999. Svoboda slova: dve storony medali (oskorblenie v zerkale yurisprudentsii i lingvistiki) [Freedom of Expression: Two Sides of the Coin (Insult in Jurisprudence and Linguistics]. GolevN.D., ed. Yurislingvistika-1: Problemy i perspektivy: mezhvuz. sb. nauch. tr. [Legal Linguistics 1:Problems and Prospects. Interuniversity. Collection of Scientific Works]. Barnaul. Izd-vo Altayskogo universiteta, pp. 106-121.

Koryakovtsev A.V., Golovacheva O.V., 2004. $\mathrm{K}$ probleme invektivnogo funktsionirovaniya yazyka i leksikograficheskogo opisaniya russkoy invektivnoy leksiki [On the Problem of the Injective Functioning of the Language and the Lexicographic Description of Russian Invective Vocabulary]. Golev N.D., ed. Yurislingvistika: yuridicheskie aspekty yazyka $i$ lingvisticheskie aspekty prava [Legal Linguistics: Legal Aspects of the Language and Linguistic Aspects of Law]. Barnaul, Izd-vo Altayskogo universiteta, pp. 216-225.

Ivanov L.Yu., Skovorodnikov A.P, Shiryaev T.N., eds., 2007. Kultura russkoy rechi: entsikl. slov.-sprav. [Culture of Russian Speech. Encyclopedic Reference Dictionary]. Moscow, Flinta Publ., Nauka Publ. 840 p.

Kusov G.V., 2013. Diagnostika kvalifitsiruyushchego priznaka «neprilichnaya forma» v sudebnoy lingvisticheskoy ekspertize [Diagnosing the Indicators of Indecency in Linguistic Expressions in Forensic Examination]. Kultura $i$ tekst, no. 1 (14), pp. 93-114.

Melikyan V.Yu., 2019. Metodologiya i praktika yuridizatsii invektivnoy leksiki [Methodology and Practice of Legalization of Invective Vocabulary]. IX Vserossiyskaya nauchno- prakticheskaya konferentsiya «Yazyk i pravo: Aktualnye problemy vzaimodeystviya» (15 noyabrya 2019 g.) [9 $9^{\text {th }}$ All-Russian Scientific and Practical Conference "Language and Law: Actual Problems of Interaction" (November 15, 2019)]. URL: http://www.ling-expert.ru/ conference/langlaw9/melikyan-2019.html (accessed 12 October 2019).

Nemirova N.V., 2015. Pretsedentnost politicheskogo prognozirovaniya $\mathrm{v}$ gazetnom diskurse [Precedential Character of Political Prediction in Newspaper Discourse]. Politicheskaya lingvistika [Political Linguistics], no. 3 (53), pp. 148-155.

Osadchiy M.A., 2012. Russkiy yazyk na grani prava: Funktsionirovanie russkogo yazyka v usloviyakh pravovoy reglamentatsii rechi [Russian Language on the Verge of Law: Functioning of the Russian Language Under Legal Regulation of Speech]. Moscow, LIBROKOM Publ. 254 p.

Searle J.R., 1999. Klassifikatsiya illokutivnykh aktov [Classification of Illocutionary Acts]. Zvyagintsev V.A., Uspenskiy B.A., GorodetskiyB.Yu., ed. Zarubezhnaya lingvistika. Vyp. II [Foreign Linguistics. Iss. II]. Moscow, Progress Publ., pp. 229-253.

Solopova O.A., 2017. Metafora v modelirovanii budushchego: "svetlyy» stsenariy (na materiale prognosticheskikh tekstov o Rossii otechestvennogo, amerikanskogo i britanskogo politicheskikh diskursov XXI veka) [Metaphor in Modeling the Future: The Best-Case Scenario (Based on Political Discourses of Russia, the Usa and Great Britain, the $21^{\text {st }}$ Century)]. Vestnik Tomskogo gosudarstvennogo universiteta. Filologiya [Tomsk State University Journal of Philology], no. 46, pp. 55-70. DOI: 10.17223/ $19986645 / 46 / 5$.

Solopova O.A., Voroshilova M.B., 2018. Emotivnyy potentsial prognosticheskogo teksta (na materiale britanskogo politicheskogo diskursa XIX veka) [The Emotional Potential of a Prognostic Text (Based on British Political Discourse of the $19^{\text {th }}$ Century)]. Kommunikativnye issledovaniya [Communication Studies], no. 4 (18), pp. 141-156. DOI: 1025513/2413-6182.2018.4.141-156.

Sternin I.A., 2008. Izbrannye raboty. Teoreticheskie $i$ prikladnye problemy yazykoznaniya [Selected Works. Theoretical and Applied Problems of Linguistics]. Voronezh, Istoki Publ. 596 p.

Sheygal E.I., 2000. Kategoriya prognostichnosti v politicheskom diskurse [The Category of Predictability in Political Discourse]. Krasnyh V.V., Izotov A.I., eds. Yazyk, soznanie, kommunikatsiya: sb. st. [Language, Consciousness, Communication. 
Collected Articles]. Moscow, MAKS-Press Publ., iss. 14, pp. 77-83.

Chudinov A.P., Solopova O.A., 2015. Linguistic Political Prognostics: Models and Scenarios of Future. Procedia - Social and Behavioral Sciences, vol. 200, pp. 412-417.

Nowak J., Rotunda R., Young J., 1986. Constitutional Law. Saint Paul, West. 1191 p.

\section{SOURCES AND DICTIONARIES}

Kuznetsov S.A., ed. Bolshoy tolkovyy slovar russkogo yazyka [Great Dictionary of Russian Language]. Saint Petersburg, Norint Publ., 1998. 1534 p. URL: http://gramota.ru/slovari/dic (accessed 12 July 2019).

Vlasov V. «Uchitelskaya gazeta» ne lyubit uchiteley? [Does "The Newspaper for Teachers" Not Like Teachers?]. URL: http://nasha-molodezh.ru/ blogs/viktor-vlasov/uchitelskaya-gazeta-nelyubit-uchiteley.html (accessed 12 July 2019). Grazhdanskiy kodeks Rossiyskoy Federatsii [Civil Code of the Russian Federation]. URL: https:// base.garant.ru/10164072/ (accessed 12 July 2019).

Kak Putin posyagal na chest sazhevogo oligarkha. I chem eto konchilos [How Putin Encroached Upon the Honor of the Black Carbon Magnate and How It Ended]. Biznes Kurs, 2018, no. 21, pp. 20-21.

Kodeks RF ob administrativnykh pravonarusheniyakh [Code of Administrative Offences of the Russian Federation]. URL: http://koapkodeksrf.ru (accessed 12 July 2019).

Kodeks professionalnoy etiki rossiyskogo zhurnalista Soyuza zhurnalistov Rossii [Code of Professional Ethics of the Russian Journalist of the Union of Journalists of Russia], 1994. URL: https://www.presscouncil.ru/teoriya-i-praktika/ dokumenty/633-kodeks-professionalnoj-etikirossijskogo-zhurnalista (accessed 12 June 2019).

\section{Information About the Author}

Oksana S. Issers, Doctor of Sciences (Philology), Professor, Dean of the Faculty of Philology and Media, Dostoevsky Omsk State University, Prosp. Mira, 55a, 644077 Omsk, Russia, isserso@mail.ru, https://orcid.org/0000-0003-4027-6346

\section{Информация об авторе}

Оксана Сергеевна Иссерс, доктор филологических наук, профессор, декан факультета филологии и медиакоммуникаций, Омский государственный университет им. Ф.М. Достоевского, просп. Мира, 55a, 644077 г. Омск, Россия, isserso@mail.ru, https://orcid.org/0000-0003-4027-6346 